\title{
Abstracts of Papers Presented at the Annual Meeting
}

\author{
SESSION 1A: BOOMS AND BUSTS IN THE LONG RUN
}

The Collapse of the Continental Dollar: The Turning Point and Its Causes, An Alternative History of Financing the American Revolution, 1775-1781

An alternative history of the continental dollar is constructed from the original laws passed by Congress. The continental dollar was a zero-interest bearer bond, not a fiat currency. The public could redeem it at face value in specie from the National Treasury at fixed future dates. How, when, and where the public was informed of this is traced through available broadsides and newspapers. Being a zero-interest bearer bond, a continental dollar's current value was the reduction off its face value discounted back from its future redemption date. Discounting must be separated from depreciation to determine when the continental dollar collapsed. There was no depreciation before 1779, only discounting. Congress' ex post facto law of 14 January 1779 that altered the redemption dates of past continental dollars and did so in a way that was not fiscally credible was the turning point. Free-fall depreciation and collapse followed hard on this legislation.

FARLEY GRUBB, University of Delaware

\section{Years of Booms and Busts: What Drives Mineral Commodity Prices?}

This paper examines the dynamic effects of demand and supply shocks on mineral commodity prices. It offers empirical insights at the example of annual market data for copper, lead, oil, tin, and zinc over the period 1850 to 2009. Using a structural vector autoregressive model, I find that prices are mainly driven by quite persistent demand shocks rather than supply shocks. At the same time, supply is rather price-inelastic in the short term, but in the medium term mineral commodity production expands and prices fall again. In the long run, prices show a decreasing or stable trend. My research suggests that the rapid industrialization in China and other emerging economies might cause prices to fall in the long run.

MARTIN STÜRMER, University of Bonn

\section{Globalization and the Current Financial Crisis in Historical Perspective}

In this paper, we compare the current financial crisis and the Baring crisis of 1890 , which was short-lived and did not drag the world into a severe recession. We demonstrate the similarities between the two episodes in terms of background and potential impact on the world economy. We then analyze the differences between the two episodes that may account for the different effects of the two crises: the decision of the Bank of England to bailout Brings versus the decision by the FED to let Lehman Brothers file for bankruptcy; the degree of comovement of financial assets; and the macroeconomic stability of the core of the global financial system. We show that the extent of comovement was much smaller than now and the macroeconomic stability of the financial system was much greater than today. With hindsight, we conclude that historical accounts which attribute the successful 
resolution of the Baring crisis to the actions of the Bank of England are probably incomplete; the Bank's actions might not have been sufficient had the macroeconomic position of England been weaker (like that of the United States today) and had financial markets experienced more contagion (like financial markets today).

NATHAN SUSSMAN, Hebrew University and CEPR, and YISHAY YAFEH, Hebrew University and CEPR

\section{SESSION 1B: BACK TO THE LAND}

Risk, Agricultural Technology, and Contractual Choice: Evidence from Confucius's Lineage in Late Qing China (1759-1901)

This paper provides micro-evidence for the agricultural stagnation debate in late Imperial China, exploiting a novel data set gathered from rent collection books of Confucius's Family (1759-1901). Based on land tenure information, we assess the effects of technological change, wheat-soybean double-cropping, on crop yields and agricultural contractual choice. We find that wheat-soybean double-cropping significantly increased crop yields, though not as large as to double the output per acre. Fixed-rent contracts were more likely to be chosen than share contracts after wheat-soybean double cropping was adopted, controlling for selectivity problem. Kin tenants were more likely to use fixed-rent contracts because they were better insured through the kin network. Lastly, our results are in support of a positive relationship between plot size and the adoption rate of double-cropping when there are fixed transaction costs and information acquisition costs.

HELEN YANG, George Mason University

The Demographic Response to Output Crisis in Rural Society: Grain Production, Mortality, and Fertility in Eighteenth-and Nineteenth-Century Sweden

Demographic responses to economic crises are important indicators of the robustness of a society, and the efficiency of its institutions. In previous research, considerable attention has been devoted to the impact of grain price fluctuations on mortality, marriage, and fertility in preindustrial society. Often, prices are assumed to be a proxy for harvest outcome, and even though this might be a reasonable assumption at very high levels of aggregation, it is clearly not as reasonable when looking at local communities. In this paper, we study the demographic response to short-term fluctuations in local grain output, and focus special attention on the impact of output crises on mortality and fertility using panel data for 274 localities in southern Sweden between 1750 and 1860. The demographic outcomes are measured by the general fertility rates and age-specific mortality rates, and local grain production is assessed using data from a recently assembled production database covering more than 2,000 farms (about 80,000 observations).

MATS Olsson, Lund University, and MARTIN DRIBE, Lund University, and PATRICK SVENSSON, Lund University 


\section{The Long-Term Impact of the Thirty Years War: What Grain Price Data Reveal}

This paper offers the first quantitative assessment of the effects of the Thirty Years War on market integration and trade. It asks, first, to what extent, if any, did the Thirty Years War lead to disintegration in grain markets? Second, how long did it take markets to recover from the impact of war? The analysis relies on a new grain price data set for 1550-1790 that covers more than 80 markets and more than 300,000 observations on price differentials between markets. We take nonrandom, systematic deviations from the Law of One Price as indicators of trade costs. Employing a paneldata framework, the paper argues that the Thirty Years War had a much stronger effect on price differentials than any other war between 1550 and 1790 and this was due to its extraordinary length that disrupted commercial links for several decades. However, while the war interrupted integration and led to increasing price differentials between markets, it did not cause lasting trend reversal: price differentials declined again from the late seventeenth and early eighteenth centuries, albeit at regionally different speeds.

MAX-STEPHAN SCHULZE, London School of Economics, and OLIVER VOLCKART, London School of Economics

\section{SESSION 2A: BANKING, FINANCE, AND TRADE IN EARLY MODERN AND MODERN FRANCE}

\section{Looking on English and German Banking in the French Mirror: Banking and Development in France (1880-1913)}

From Gerschenkron paradigm on economic backwardness questions rose up about the effectiveness of banking structures for economic development. Even though initial arguments are quite obsolete by now, debates remain especially tough in the microeconomic of banking field. In accordance with this literature, we develop an easy model that takes account of the access to private information conditionally to the bank size. We prove that small banks lend to risky projects while large banks work with safe clients. We match the model with the French experience of the classical period (1880-1914) and show that theory fits the facts. Regard to the importance of regional industries in the French development, we do the hypothesis that small banks financed growth. Therefore, the paper looks for correlations between local banking, innovation and growth through panel data analysis on a spatial basis. We use to this end a new data set on GDP growth, innovation, and bankruptcy. Results support our main hypotheses. Also, with regard to the importance of local knowledge in the German system, this contribution brings clues on the German versus English banking debate and supports the German advantage hypothesis.

Guillaume Bazot, Paris School of Economics

\section{The Belle Epoque of International Finance: The French Portfolio, 1880-1913}

This paper introduces a new data set of French investments in foreign securities. This is the most detailed data available to date. The data is used to study the composition, valuation, and total return of the French portfolio of non-sovereign foreign securities on the 34 years before World War I. Additional insights are obtained about the structure of the financial market in France. 
Financing Long-Distance Trade without Banks: The Joint Liability Rule and Bills of Exchange in Eighteenth-Century France

By the close of the seventeenth century, international trade had expanded beyond the reach of the personal networks on which it had previously depended. How was long-distance trade among strangers financed without banks or international enforcement? I argue that a particular seventeenth-century legal innovation, the joint liability rule, enabled the medieval bill of exchange to become the dominant means of payment and credit in the early modern period, thus supporting an unparalleled expansion of trade. The joint liability rule specified that every party who used a bill of exchange to pay for goods or settle a debt was liable for the face value of the bill if it was not paid at maturity. This paper examines the role that joint liability played in ameliorating three fundamental problems in long-distance trade finance: moral hazard between issuers and payers, adverse selection in the market for bills, and imperfect enforcement of international contracts. To this end, I have compiled a new data set spanning the period from 1780 to 1790 that includes thousands of original bills of exchange, notices of defaulted bills, court records, and business letters of Maison Roux, a large French merchant house. I show that the joint liability rule put in place a formal mechanism that linked otherwise distinct personal networks so that trade could expand beyond the limits any single network could support. Despite evidence of ongoing problems of adverse selection and moral hazard, my findings demonstrate that bills of exchange worked to broaden trade in the sense that agents used them across business networks.

VERONICA SANTAROSA, Yale University

\section{SESSION 2B: INSTITUTIONS IN THE DEVELOPING WORLD}

Understanding Development in the Modern World: Power, Beliefs, and Institutions, with an Application to Brazil, 1960-2010

Why haven't more countries achieved sustained economic development given the presence of role models in the modern world? We present a framework to analyze development; and apply the framework to understand the transition in Brazil over the past half-century with an emphasis on 1994 as a "turning point" to a virtuous path of institutional changes. Our framework consists of interconnected concepts: power, beliefs, institutions, windows of opportunity, and leadership. The dynamics amongst these elements produces outcomes that may induce changes in economic and political openness. Development is viewed as following a punctuated path which produces either incremental changes in institutions or big changes in institutions when the rental streams from institutions no longer match the expectations of those in power. The hyperinflations in Brazil prior to 1994 instilled a latent belief in macro-stability that President Cardoso tapped, and which allowed him to sustain a series of virtuous institutional deepening.

LEE ALSTON, University of Colorado and NBER, MARCUS MELO, University of Pernambuco,

BERNARDO MUELlER, University of Brasilia, and CARlos PereIra, Michigan State University 
Structural Impediments to African Growth? Countervailing Evidence from Real Wages in British Africa, 1880-1960

Recent literature on the historical determinants of African poverty emphasizes structural impediments to growth, such as adverse geographical conditions, weak institutions, and ethnic heterogeneity. The evidence is mainly drawn from cross-country regressions on late-twentieth-century income levels, assuming persistent effects over time. But has African poverty truly been a persistent historical phenomenon? Our study casts doubt on this view. We show that recent work on the long-term growth effects of the slave trades is neither robust for pre-1970s GDP/capita levels, nor for pre-1973 and post-1995 growth rates. We push existing African income estimates back in time by calculating urban unskilled real wages in British Africa (1880-1960), adopting Allen's (2001) subsistence basket methodology. We find that real wages were well above subsistence level and rose significantly over time. Moreover, West African and Mauritian real wage levels were considerably higher (up to 300 percent) than those in major Asian economies. The inability of recent literature to take strong fluctuations in economic performance into account, can thus severely limit its explanatory power.

MARLOUS VAN WAIJENBURG, Northwestern University, and EWOUT FRANKEMA, Utrecht University

\section{Impact of African Independence on the Welfare of South African Blacks}

The 1970s were a turning point for the labor market in South Africa. The old system which had created a docile, cheap black labor force was rapidly disintegrating. In manufacturing, increased demand for machine operatives led to the dismantling of racial job reservation. While in mining, a series of events external to South Africa dramatically cut the foreign labor supply. The result was an increase in employment in some regions of the country and a consequent increase in the welfare of blacks in those regions. This paper focuses on the shock to the foreign labor supply to the mining industry between 1975 and 1979 and its impact on the welfare of people in the South African provinces who replaced the foreign workers. I do a difference in difference analysis comparing the welfare of people born in the affected region before and after the shock to people born in the unaffected regions.

MARTINE MARIOTTI, Australian National University

SESSION 2C: INDUSTRIALIZATION AND INNOVATION

\section{Fukoku kyohei: Evaluating the Impact of Public Investment in Meiji Japan, $1868-1912$}

Weak institutions, capital scarcity, and risk aversion may motivate the state to lead industrialization in developing economies. Nevertheless, it is unclear whether sectors targeted by the government achieve the aims of officials, especially compared to those led by private investors. Assessment is further complicated by unpredictable budget constraints during fiscal and monetary crises. Using a new data set of firm establishment from prewar Japan, I present some stylized facts about the development of industries pioneered by either the government or entrepreneurs. I find public investment was directed toward both capital-intensive and export-oriented sectors 
and in less populated regions, consistent with policy aims. Public-led sectors also had higher rates of entry among startup firms, even in the latter half of the period when capital market access improved. Together, these features suggest persistent risk aversion among entrepreneurs in sectors not endorsed by the government even after the withdrawal of direct financial support.

JoHN TANG, Australian National University

\begin{abstract}
How Fast and How Broad was British Industrialization? Evidence from a Synthetic Occupational Census for 1801
\end{abstract}

Using the 1851 occupational census and contemporary trade directories, we show that it is possible to infer occupational structure from trade directories. Taking a stratified sample of 100,000 businesses from the Universal British Directory, we then estimate local and national occupational structures in England and Wales in 1801. Classifying the 1801 occupations using the censal system of 1851 enables us to track changes in male and female employment. We find an increase in industrial employment similar to Crafts-Harley, and much faster than that implied by Shaw-Taylor. Industrialization was broad, consistent with Temin's findings on export growth.

LiAM BRUNT, Norwegian School of Economics, and ERIK MEIDELL, Norwegian School of Economics

Industry Connections and the Geographic Location of Economic Activity: Evidence from Nineteenth-Century Britain

This paper provides causal evidence that interindustry connections, such as those suggested by Marshall (1920), can influence the geographic location of economic activity. To do so, it takes advantage of a large, exogenous, temporary, and industryspecific shock to the nineteenth-century British economy. The shock was caused by the U.S. Civil War, which sharply reduced raw cotton supplies to Britain's important cotton textile industry, causing a four-year recession in the industry. The impact of the shock on towns in Lancashire County, the center of Britain's cotton textile industry, is compared to towns in neighboring Yorkshire County, where wool textiles dominated. The results suggest that this trade shock reduced employment and employment growth in industries related to the cotton textile industry, in towns that were more severely impacted by the shock, relative to less affected towns. The impact still appears over two decades after the end of the U.S. Civil War. This suggests that temporary shocks, acting through interindustry connections, can have long-term impacts on the distribution of industrial activity across locations.

W. WALKer Hanlon, Columbia University

\title{
PLENARY SESSION: LESSONS FOR THE FUTURE: INTERNATIONAL CAPITAL MARKETS IN HISTORICAL PERSPECTIVE
}

The paper focuses upon three subjects: the different characteristics of international capital markets in the first period of ascendance between 1870 and 1914 and the second post-1970 rapid increase; the political economy of Latin American reliance 
upon international capital inflows in both of these periods; and the current sovereign debt problem of the developed countries.

On the first topic, there were important differences between the surges of globalization during the two intervals. Pre-World War I, real capital transmission dominated, while the second involved financial integration led by the richer countries. The first period was accompanied by the spread of a broad-based gold standard, while the second has been consistently lacking in any degree of centralized management, whether the G-7, the IMF, or the recently created G-20. Lastly, economic interdependence was extensive in character before 1914 with capital and migratory flows, whereas in recent years the emphasis has shifted to the technological convergence.

Political economy stands out in the specific Latin American case. Two subjects are discussed. Why was it possible for all the principal regional economies to move to a gold standard before 1914? My answer is found in the favorable terms of trade that favored agricultural interests while the rising industrial sector could benefit from high tariffs. Thereby, the implicit conflict between rural and urban interests, and between domestic and international markets, that surged later, could be minimized. Why did debtor's cartels fail to catch on in the 1980s? National interests prevented the degree of cooperation needed to assure success of such an undertaking.

Finally, the diverse strategies of the United States and the European Union in coping with the Great Recession and the consequent rise in indebtedness are discussed. The United States has emphasized fiscal deficits whereas the European Union has stressed their elimination as the means of coping. The issue, in fact, is the timing of both necessary steps. No double dip will occur in the United States, nor will the euro disappear. Return to continuous global growth, real and financial, and the importance of the developing world in that process, is what is needed.

AlBert Fishlow, Columbia University, Speaker JEFFRY FRIEDEN, Harvard University, Commentator

\section{SESSION 3A: MONEY, TRADE, AND INNOVATION DURING THE INTERWAR PERIOD}

\section{Innovation and British Regions in the Interwar Period}

This paper investigates the regional distribution of innovation in Britain in the interwar period and contributes to the debate concerning the role played by corporate innovation in the relative decline of British industry. The paper is based on a novel data set including more than 8,000 patents granted in the United States to British inventions in three benchmark periods. This data set enables us to study the Revealed Technological Advantage (RTA) of British regions - the first time this has been done for this period-thus identifying those technological fields where regions held an international technological advantage. The analysis shows that corporate innovation and preexistent technological specialization had an impact on the regional RTA and suggests regional and corporate technological lock-in. These findings support the argument that corporations were responsible for a considerable share of innovation. However, only to a limited extent was such innovation taking place in the fastest growing sectors. 
How Did Takahashi Korekiyo Rescue Japan from the Great Depression?

Japan achieved an early recovery from the Great Depression in the 1930s. A veteran finance minister, Takahashi Korekiyo, brought it about by a combination of expansionary exchange rate, fiscal, and monetary policies. To explore the effect of Takahashi's macroeconomic policy stimulus measures during the early 1930s in Japan, we construct a six-variable structural vector autoregression (S-VAR) model. The variables include output, price, fiscal policy, exchange rate, money, and inflation expectations. Our analysis reveals that changes in the exchange rate played the most important role as an independent policy measure while monetary and fiscal policies had much less effect throughout the early 1930s. Especially, during the second half of 1931, speculation on Japan's departure from the gold standard and the consequent predicted inflation turned people's expectations from deflation to inflation well ahead of the actual departure in December 1931. The effects of fiscal policy were limited. Monetary policy largely accommodated exchange rate and fiscal policies.

MASAHIKO SHIBAMOTO, Kobe University, and MASATO SHIzUME, Bank of Japan

\section{Did France Cause the Great Depression?}

The gold standard was a key factor behind the Great Depression, but why did it produce such an intense worldwide deflation and associated economic contraction? While the tightening of U.S. monetary policy in 1928 is often blamed for having initiated the downturn, France increased its share of world gold reserves from 7 percent to 27 percent between 1927 and 1932 and effectively sterilized most of this accumulation. This "gold hoarding" created an artificial shortage of reserves and put other countries under enormous deflationary pressure. Counterfactual simulations indicate that world prices would have increased slightly between 1929 and 1933, instead of declining calamitously, if the historical relationship between world gold reserves and world prices had continued. The results indicate that France was somewhat more to blame than the United States for the worldwide deflation of 1929-1933. The deflation could have been avoided if central banks had simply maintained their 1928 cover ratios.

Douglas IRwin, Dartmouth College and NBER

\section{SESSION 3B: PUBLIC HEALTH AND DEMOGRAPHIC CHANGE IN ECONOMIC HISTORY}

Ironing Out Deficiencies: Evidence from the United States on the Economic Effects of Iron Deficiency

Iron deficiency reduces productive capacity in adults and impairs cognitive development in children, causing worldwide losses that reach into the billions of dollars. In 1943 the United States government issued War Food Order No. 1, which required the fortification of bread and flour with iron to reduce deficiency in the working-age population during World War II. This universal fortification of grain products increased per capita consumption of iron by 16 percent. I use the exogenous timing of the federal law and the "Study of Consumer Purchases in the United States 1935-1936" to measure the economic effects of the fortification program. Areas with lower levels of iron experienced greater increases in wages and school attendance 
between 1940 and 1950. A long-term follow up suggests adults in 1970 with more exposure to fortification during childhood received higher wages, more years of schooling, and were less likely to live in poverty.

GREGORY NIEMESH, Vanderbilt University

\section{Urban Fertility Responses to Local Government Programs: Evidence from the 1923-1932 United States}

This paper investigates whether the public health education and poverty relief programs that occurred in the United States prior to the New Deal had the unintended effect of reducing fertility in American cities. Understanding the relationship between these programs and fertility in American municipalities is important both from an historical perspective as well as for informing current policy. If these programs reduced fertility within these cities, they potentially offer a tool for governments looking to do the same, as well as illuminate any potential unintended effects. Additionally, determining whether these programs affected fertility will shed light on why fertility rates were declining steadily prior to the Great Depression. Fixed-effects estimates suggest that both spending on public health education and poverty relief were strongly associated with reductions in fertility across the cities. Furthermore, fertility rates in these areas were much more sensitive to municipal investments in health education.

Jonathan Fox, Max Planck Institute for Demographic Research, and MikKo MYRSKYLÄ, Max Planck Institute for Demographic Research

\section{Coal, Smoke, and Death}

The use of coal for home and commercial heating increased rapidly, peaked in the mid-1940s, and declined sharply. The switch to cleaner fuels was driven by declining relative prices for natural gas and fuel oil, the end of war-related supply restrictions, and a series of coal strikes from 1946-1950. This paper documents these trends and uses newly digitized monthly data to estimate the mortality effects of this decline in coal consumption for heating over the period 1933-1958. The mortality effects are identified by variation in coal for heating across seasons, over time, and across states. In the Northeast, Midwest, and West, a 10 percent decline in retail coal consumption was associated with a $0.3-0.4$ percent decline in overall mortality during JanuaryMarch. The effects of expanded use of coal by industry and electric utilities are also examined.

AlAN BARRECA, Tulane University and Rand Corporation, KAREN Clay, Carnegie Mellon University, and JOEL TARR, Carnegie Mellon University

SESSION 3C: OPIATE OF THE MASSES AND CAPITAL ACCUMULATION: RELIGION FROM THE MIDDLE AGES TO NINETEENTH-CENTURY EGYPT

\section{Financing Cathedral Construction: An Investment in Social Overhead Capital?}

Of the many campaigns brought to fruition by the economic prosperity of the High Middle Ages, few have left evidence as perdurable or awe-inspiring as those to build 
cathedrals, abbeys, and even some parish churches in the Gothic style. Between the twelfth and early sixteenth centuries, a massive public and private investment was made in these soaring monuments to both human ingenuity and the glory of God. This paper is part of a larger project that draws upon the extant managerial accounts of numerous ecclesiastical building campaigns to explore four interrelated questions: what factors activated a cathedral building campaign; in what combination of ways were they financed; who were the direct or indirect beneficiaries of the investment they embodied; and finally, were these monuments intended to glorify the achievements of mankind or the greatness of God; to leave their worshippers humbled by fear and trembling or exuberant with wondrous ecstasy, or possibly both? History suggests that moments of open societal opportunity of the kind required for artistic and technical genius to emerge and flourish, such as that witnessed in the Gothic triumph, are usually facilitated by a concomitant broad economic prosperity. This project seeks to understand much more completely than has been accomplished thus far by historians working within single disciplines, the connections between the technical, artistic, intellectual, and spiritual achievement that is Gothic church construction and the material foundations from which it took flight.

ANNE MCCANTS, Massachusetts Institute of Technology, and PAUl HoHENBERG, Rensselaer Polytechnic Institute

\section{Printing and Protestants: Reforming the Economics of the Reformation}

The causes of the Protestant Reformation have long been debated. This paper attempts to revive and econometrically test the theory that the spread of the Reformation is linked to the spread of the printing press. The proposed causal pathway is that the printing press permitted the ideas of the Reformation to reach a broader audience. I test this hypothesis by analyzing data on the spread of the press and the Reformation at the city level. An econometric analysis which instruments for omitted variable bias suggests that within the Holy Roman Empire, cities with a printing press by 1500 were 19 percentage points more likely to be Protestant by 1560 . This result weakens over time and across Europe, indicating that the press was important for the initial spread - but not necessarily the persistence — of the Reformation.

JARED RUBIN, Chapman University

\section{Laborers, Scribes, and Financiers: Modernization and Interreligious Human Capital Differentials in Mid-Nineteenth-Century Egypt}

Using a new and unique source of data from nineteenth-century Egypt and the 1848 and 1868 individual-level census records, I examine the impact of an early state-led modernization program in manufacturing and transportation on the human capital differences between Muslims, Christians, and Jews, which were traditionally in favor of non-Muslims. I find that modernization widened the interreligious occupational gap in both 1848 and 1868; however, while Muslims experienced downward occupational mobility in the modern sector in 1848, they enjoyed upward mobility in 1868. I then examine, as the underlying mechanism behind these findings, the effectiveness of modernization in making the transition from the religiously segregated guild system into the more homogeneous labor force. I show that 
modernization, by creating new occupational opportunities and new neighborhoods that were less religiously segregated, acted as a "melting pot," that was nonetheless too limited to counteract the gap-preserving role of the hereditary guild system.

MoHAmEd SALEH, University of Southern California

\author{
SESSION 4A: NETWORKS AND MARKETS: INTEGRATION AND DISINTEGRATION
}

\title{
Railroads and Productivity Growth During the Depression
}

Financial boom-bust cycles misallocate capital in an upswing. And the downswing deprives an economy of capital accumulation that might have taken place. These are both negative influences on the trend growth rate of productivity. But can there be a "silver lining," a compensatory beneficial effect? The answer is nuanced. Like individuals, firms and sectors exhibit a diversity of response to adversity. Some become moribund and ultimately fail. Others are spurred to technological and organizational innovation, with persisting long-run consequences. Railroads during the Great Depression were one such sector. Between 1929 and 1941 the number of employees, locomotives, and rolling stock dropped by about a third, but freight ton miles increased and passenger miles were within 6 percent of 1929 levels. This paper considers the innovations that enabled this and uses firm-level Interstate Commerce Commission data to explore the determinants of labor and total factor productivity growth between 1929 and 1941.

AleXANDER J. FIELD, Santa Clara University

Panics and the Disruption of Private Payments Networks: The United States in 1893 and 1907

We analyze the impact of the 1893 and 1907 panics on the national payments system through the lens of domestic exchange markets, where interior banks bought and sold New York funds. Using daily data, we chart the effects of the panic and subsequent cash restrictions across cities. We show that the degree of disruption in regional financial centers was increasingly a function of their place or centrality in intercity correspondent networks rather than of local conditions and then provide both qualitative and quantitative evidence on the effects of such payments disruptions on real economic activity. While pre-Federal Reserve private payments networks were normally quite efficient, when convertibility of New York balances was threatened or limited, they also proved to be important channels for transmitting financial pressures. Such restrictions, in turn, had serious consequences for payments settlement and consequently for the level of economic activity.

JOHN A. JAMES, University of Virginia,

DAVID F. WEIMAN, Barnard College, and JAMES MCANDREWS, Federal Reserve Bank of New York

Business Cycles in South-East Europe, 1870-2000: A Bayesian Dynamic Factor Model

Based on a freshly built data set and relying on a dynamic factor model, this paper constructs business cycle indices for five South-East European (SEE) countries 
(Austria-Hungary, Bulgaria, Greece, Romania, and Serbia/Yugoslavia) to address two questions: to what extent has there been a common SEE business cycle, and has there been synchronization of business cycles with England, France, and Germany? We find limited but increasing business cycle integration before World War I, both within SEE and vis-à-vis the core economies. The trend towards increasing levels of business cycle synchronization accelerates in the interwar period and is not even interrupted by the arrival of the Great Depression. The onset of the Cold War almost completely extinguishes regional business cycle integration, but the increased economic links of some Communist countries with the West (early on by Yugoslavia, from the mid1970s also by Romania) also sees the reemergence of a common business cycle vis-àvis Austria and Germany.

MATTHIAS MORYS, University of York, and MARTIN IVANOV, Bulgarian Academy of Sciences

\section{SESSION 4B: WAGES, KIDS, AND CAREERS}

The Impact of Female Employment on Male Wages and Careers: Evidence from the English Banking Industry, 1890-1914

This paper examines the consequences of the employment of women in the English banking industry on the salaries and career opportunities of men in the industry during the interwar period. Male bank clerks believed that women were being employed by the banks to undercut their salaries. Conversely, the banks and women argued that occupational segregation kept most women in routine positions, and this actually improved the likelihood that men would be promoted to positions of responsibility and ultimately increase their salaries. These claims are tested using the personnel records of Williams Deacons Bank, a medium-sized branch bank based in Manchester. Difference-indifference regressions on male salaries suggest that women were substitutes for younger men, but complements to senior men.

ANDREW SELTZER, Royal Holloway, University of London

\section{The Beckerian Family and the English Demographic Revolution of 1800}

In England in 1800 a profound change occurred that created an important component in the regime of modern economic growth. In preindustrial England, from 1250 to 1800 , the rich produced more children than the poor. After 1800 the association between wealth and fertility reversed. Richer families stopped using their wealth to accumulate more children, and instead the poor became the higher fertility class. Why this change? Using measures of the wealth and occupation of fathers and sons 1500-1914, the paper tests whether we can explain this through the qualityquantity tradeoff in children becoming more Beckerian after 1800. Surprisingly, the evidence is that the costs of more children in terms of quality were higher before 1800 than after. The increased importance of human capital did not increase the costs of greater fertility. The demographic revolution of 1800 was not a response to changing costs, but a true revolution in aspirations.

GREGORY ClARK, University of California, Davis, and NeIL Cummins, CUNY-Queens College 
Convergence and Catch-Up at the Periphery? Living Standards in the Habsburg Empire, 1829-1910

This paper analyzes a brand new series of prices and wages for the territories once encompassed by the Habsburg Empire. Stretching back to 1829, the real wage series are the first continuous and consistent economic indicator of changing living standards in this part of Europe before and during the times of industrialization. The series confirm an overall West-East gradient both in terms of wages and prices. The differences in living standards were quite substantial with workers in the poorest province earning only 43 percent (in real terms) of what their Viennese counterparts earned in 1910. Differences in growth rates were even starker. Bohemia and Silesia were the fastest growing regions (at an average rate of 1 percent p.a.) while Croatia and Transylvania experienced a long-term decline in real wages of $0.2-0.4$ percent p.a. Most of the growth in living standards occurred between 1850 and 1873 and again from 1896 to 1910 .

TOMAS CVRCEK, Clemson University

SESSION 4C: YOU CALL THAT (TECHNOLOGICAL) PROGRESS?

Turning Points in Leadership: Shipping Technology in the Portuguese and Dutch Merchant Empires

This paper focuses on the implications of organization on the race for economic leadership across merchant empires. Poor organizational choices reduce incentives to invest, which in turn stifle technological improvements and make leading empires lag behind new entrants. Using historical evidence on shipping technology, I show that this may have been a factor behind the loss of leadership of the Portuguese merchant empire in the late sixteenth century.

Claudia ReI, Vanderbilt University

\section{Was Mechanization De-Skilling? The Origins of Task-Biased Technical Change}

Did nineteenth-century technology reduce demand for skilled workers in contrast to modern technology? I obtain direct evidence on human capital investments and the returns to skill by using microdata on individual weavers and an engineering production function. Weavers learned substantially on the job. While mechanization eliminated some tasks and the associated skills, it increased returns to skill on the remaining tasks. Technical change was task-biased, much as with computer technology. As more tasks were automated, weavers' human capital increased substantially. Although technology increased the demand for skill like today, weavers' wages eventually increased and inequality decreased, contrary to current trends.

JAMES BESSEN, Boston University School of Law 
The Origins of the Anglo-American "Productivity Gap" in Electronics: The British and American Interwar Radio Equipment Industries

This paper examines the evolution of radio manufacturing in Britain and the United States prior to World War II; the extent of the Anglo-American "productivity gap"; in radio, and the causes underpinning Britain's lower productivity. British labor productivity is shown to be substantially below American levels, though better than was suggested by earlier studies. A major cause of lower productivity was Britain's socio-legal environment, which prioritized protecting private property rights even when these created monopoly positions. Marconi developed a powerful British radio patent pool, with royalty fees levied on the number of tubes per radio. This both limited the scope for cost-reducing innovations and biased technical development towards multifunctional tubes which were much more expensive to produce, yet lowered manufacturers' production costs by reducing royalty liabilities. This in turn reinforced the tight cartel of Britain's tube manufacturers, who were also able to extract monopoly rents from the sector.

PETER SCOTT, University of Reading

\section{SESSION 5A: BANKING DURING THE GREAT DEPRESSION}

\section{Credit Availability and the Collapse of the Banking Sector in the 1930s}

This paper examines the mechanism through which banking sector distress affects credit availability using the experience of the United States during the Great Depression. While different mechanisms linking banking distress to economic activity have been posited, the empirical evidence regarding these mechanisms has thus far been modest. We utilize previously neglected data from a 1934 survey conducted by the Federal Reserve System of both banks and Chambers of Commerce regarding the availability of credit, and test whether different aspects of the banking system collapse affected reported credit availability. We find that bank failures had the most dominant impact, but there is also some evidence for the importance of funding constraints from deposit outflows and of protracted deposit liquidation.

\section{MARK CARLSON, Board of Governors of the Federal Reserve, and} JONATHAN ROSE, Board of Governors of the Federal Reserve

\section{Accelerating into the Abyss: Financial Dependence and the Great Depression}

The importance of bank failures in the propagation of the Great Depression remains disputed. Even the authors that view them as important are not unanimous in the mechanisms they propose. Friedman and Schwartz (1963) argued that money supply reductions in turn depressed economic activity, while Bernanke (1983) suggested bank failures raised the cost of credit intermediation. The empirical support for both interpretations has nevertheless been scant. I attempt to fill this gap by comparing how industries at the state level with different needs for outside financing performed during bank failures. Two measures, the external dependence indicator of Rajan and Zingales (1998) and the inverse interest cover, confirm the sensitivity of financially dependent industries to bank failures. I instrument bank failures with 
predetermined vulnerabilities of each state's banking system. The results suggest bank failures were a relevant predictor of U.S. manufacturing output throughout the interwar period, including the Great Depression.

Mrdjan Mladjan, Universitat Pompeu Fabra

When the Music Stopped: Transatlantic Contagion During the Financial Crisis of 1931

In 1931 a financial crisis began in Austria, struck numerous European nations, forced Britain to abandon the gold standard, and spread to the United States. Scholars debate how this crisis crossed the Atlantic. A venerable view attributes transatlantic contagion to the gold standard. A newer view attributes transatlantic contagion to links between financial institutions in the United States (particularly the financial center of New York City) and Europe (particularly Germany). This paper addresses that debate by examining data regarding banks in New York City. Banks' behavior changed little during the German crisis, while bank behavior changed substantially following other events, such as the banking panic in the United States in the fall of 1930 and Britain's abandonment of the gold standard in the fall of 1931. Banks with substantial exposure to European risks behaved in much the same way as banks without European exposure. The balance sheets of the former changed less than the balance sheets of the latter. Our results indicate the German crisis appears to have had little effect on the behavior of banks in New York City.

PATRICK VAN HORN, New College of Florida, and GARY RICHARDSON, University of California, Irvine and NBER

\section{SESSION 5B: FROM HERE TO THERE AND FROM THERE TO HERE: MIGRATION}

A Nation of Immigrants: Assimilation and Economic Outcomes in the Age of Mass Migration

We construct a novel panel data set of native-born workers and immigrants from 18 sending countries to analyze how immigrants performed in the labor market relative to U.S. natives from 1900 to 1920 , both upon first arrival and after some time spent in the country. Our panel data addresses two sources of bias inherent in cross-sectional studies of assimilation: changes in the quality of immigrant arrival cohorts over time and selective return migration. We find that: (1) on average, recent immigrant arrivals had lower skill levels than the native born circa 1900; (2) in repeated cross-sections, immigrants appear to converge upon, but not fully catch up with, natives after 20 years in the United States; (3) however, this modest convergence disappears in the panel samples, suggesting that it is driven entirely by the loss of (negatively selected) return migrants over time. We also explore heterogeneity in these patterns by country of origin.

RAN ABRAMITZKY, Stanford University, LEAH Boustan, University of California, Los Angeles, and KATHERINE ERIKSSON, University of California, Los Angeles 


\section{The Great Migration of African Americans: New Insights from Linked Census Data}

We assembled a new, linked data set for approximately 3,500 Southernborn African American males spanning 1910 to 1930, the first two decades of the "Great Migration" from the South. We use the new data set to engage major themes in research on the Great Migration, especially the determinants of the migration decision and the economic gains from migration. Because we observe the same men before and after the start of the Great Migration, we can explore both themes in unprecedented detail. Unlike previous studies, the data set includes detailed information about the migrants' original locations and childhood households and about the destinations and occupations migrants chose 20 years later. We observe the same information for "nonmigrants," short-distance migrants, and brothers, allowing them to serve as useful comparison groups.

MARIANNE WANAMAKER, University of Tennessee, and WILliam COLLINS, Vanderbilt University

The Making of Modern America: Accounting for Migratory Inflows and Outflows During the Age of Mass Migration

We estimate migrant inflows into and out of America during the Age of Mass Migration at the turn of the twentieth century. Our analysis is based on a novel data set of administrative records on 24 million migrants that entered Ellis Island, New York between 1892 and 1924. We first use these records to measure inflows into New York by gender age-nationality cohorts and then scale-up these figures to estimate migrant inflows into America as a whole. Combining these flow estimates with census data on the stock of foreign-born in America in 1900, 1910, and 1920, we conduct a demographic accounting exercise to estimate outmigration rates in aggregate and by nationality-age gender cohort. Our findings have implications for understanding the potential selection of immigrants that chose to permanently reside in America at the turn of the twentieth century, their impact on Americans, and on sending country economies.

MARTINA VIARENGO, London School of Economics and Kennedy School of Government, Harvard University, ORIANA BANDIERA, London School of Economics, and IMRAN RASUL, University College London

\section{SESSION 6A: FINANCIAL MARKETS IN PEACE, WAR, AND CIVIL UNREST}

\section{Transforming the NYSE: Market Microstructure and Liquidity During World War I}

In this paper, I investigate the performance of the NYSE during World War I, a crucial period of crisis and expansion before the advent of state regulation. Focusing primarily on a range of measures of market liquidity, I trace the impact of the waves of crisis in European and worldwide financial markets and estimate the effects on market quality (efficiency, liquidity, volatility) of the subsequent rapid expansion in listings and trading. I put these figures into perspective by comparing with modern-day market quality measures for the NYSE. 
Austerity and Anarchy: A Century of Fiscal Consolidation and Social Unrest

Efforts at fiscal consolidation are often limited because of concerns over potential social unrest. From German austerity measures during the 1930s to the violent demonstrations in Greece in 2010, hard times have tended to go hand in hand with antigovernment violence. In this paper, we assemble cross-country evidence for the period 1919 to the present about the extent to which societies become unstable after budget cuts. The results show a clear positive correlation between austerity and instability. We examine the extent to which this relationship simply captures the fact that fiscal retrenchment and economic slumps are correlated, and conclude that this is not what is driving the effect. Finally, we test for interactions with various economic and political variables. While autocracies and democracies show broadly similar responses to budget cuts, countries with a history of stable institutions are less likely to see unrest as a result of austerity measures.

HANS-JOACHIM Voth, Universitat Pompeu Fabra, and JACOPO PONTICELLI, Universitat Pompeu Fabra

Predicting Institutional Collapse? Financial Markets and Political Violence at the Onset of the Spanish Civil War

Could the outbreak of the Spanish civil war have been predicted? We explore this issue by looking at the behavior of Spanish investors in the years that preceded the dramatic events of July 1936. The paper tests the ability of financial markets to assess ex ante the risk of extreme political events which may have posed a serious threat to the survival of the existing economic and institutional order, such as a revolution or an armed internal conflict. To this end, we have reconstructed four original time series: the indexes of the Madrid and Bilbao stock exchange and the yields of government bonds on both exchanges at weekly frequency from January 1920 to July 1936. The paper tests for structural breaks in the mean and variance of the series, and explores the impact of political events on investors' expectations by using an event study approach.

STEFAn Houpt, Universidad Carlos III, Madrid, and

Stefano BAtTILossi, Universidad Carlos III, Madrid

\section{SESSION 6B: CAN YOU SPARE A DOLLAR/GUILDER/QUID UNTIL PAYDAY? SMALL- SCALE LENDING FROM THE SEVENTEENTH TO TWENTIETH CENTURIES}

\section{Loans for Salaried Employees: The Case of the Dutch East India Company, 1602-1795}

Capital markets became more important once it was possible to borrow against future revenue. Although states had long used this possibility, salary-backed loans only emerged during the late nineteenth century. They enabled people without property to borrow on the basis of their skills. Standardized wage rates and regular salary payments removed risks for lenders, but moral hazard problems remained fraught. To maximize recovery rates lenders therefore regularly intimidated borrowers. This paper shows that already between 1600 and 1800, salary-backed loans were widely used in the Dutch Republic's maritime sector. The particular labor context removed the moral hazard problems also confronted by lenders centuries later. 
High on-job mortality rates made these necessary but not sufficient conditions for their wide use. Financial intermediaries made the system viable by forming large and diversified portfolios. The large increase of mortality rates that threatened the labor supply during the late eighteenth century called for drastic measures, however.

ChristiaAn VAN Bochove, Utrecht University, and TON VAN VelzEN, Dutch National Archives

\section{Regulation and Crises in Microfinance: Irish Loan Fund Societies, 1830-1914}

Weak regulation and regulatory inaction have been cited as significant factors in the recent financial crises in Britain, Ireland, and the United States. This paper aims to contribute to debates on regulatory reform by providing an empirical study of two unique cases of regulatory failure and capture, and contagion from nineteenth-century Ireland. This paper analyses the effects of exogenous and idiosyncratic shocks to the Irish financial system in the 1840s and 1890s. The latter only affected loan fund societies-local financial quasi-mutuals that lent to nonmembers. This study utilizes a new data set on Irish loan fund societies to analyze the effect of contagion and regulatory failure and capture on unit independent financial institutions.

EOIN MCLAUGHLIN, University of Edinburgh

\section{Regulating for Legitimacy: Consumer Credit Access in France and America}

Two features of the historical context proved consequential for the way in which credit came to be legitimated. The first was the role of banks. It was the fragmented and highly competitive banking sector in the United States that led banks to offer credit, and especially revolving credit, as an inducement to attract new depositors. In France, banks were making profitable industrial loans to projects that were being supported through coordinated government policies. The second feature that set France and the United States on different trajectories was the divergence in attitudes about credit of progressive nongovernment organizations, including trade unions and other welfare and rights groups. In France, the relationship between credit and welfare was contested. France's tradition of republican citizenship implied equal treatment by the state, but not universal access to all products and services in the marketplace. In the United States, an evolving coalition of lenders and non-profit societies pushed the idea of credit access as welfare improving: from anti-loan shark campaigns in the 1920 s, to early postwar credit intended to give workers access to new household products, to campaigns in the 1970 s to extend credit to urban blacks and middle-class women. The center-left "third way" movement of the 1990s continued to embrace expanded credit access as a means to improve the welfare of the worst-off in society.

GUNNAR TRUMBULL, Harvard University 